\title{
Aniline as Corrosion Inhibitor for Zinc in Hydrochloric Acid
}

\author{
R. T. VASHI* and KRUNAL DESAI \\ Department of Chemistry, Navyug Science College, Rander Road, Surat- 395 009, \\ Gujarat, India \\ vashirajendra@yahoo.co.in
}

Received 23 October 2012 / Accepted 12 November 2012

\begin{abstract}
The corrosion of zinc in hydrochloric acid containing aniline has been studied at different acid concentrations, inhibitor concentration and temperatures. Corrosion increases with the concentration of acid and the temperature. As the concentration of inhibitor increases Inhibition efficiency (I.E.) also increases. At constant inhibitor concentration, the I.E. decreases with the increase in concentration of acid. As temperature increases, percentage of inhibition decreases. The plot of log $(\theta / 1-\theta)$ versus $\log C$ results in a straight line suggest that the inhibitors cover both the anodic and cathodic regions through general adsorption following Longmuir isotherm. Galvenostatic polarization curves show polarization of both anodes as well as cathodes.
\end{abstract}

Keywords: Corrosion, Inhibition, Inhibition efficiency

\section{Introduction}

The problem of corrosion is of considerable importance due to increase in uses of metals and alloys. Corrosion is a process that occurs when a material deteriorates due to its interaction with the surrounding environment in which an electrochemical reaction consumes the material through oxidation ${ }^{1}$. Zinc is one of the most important non-ferrous metals, which finds extensive use in metallic coating. Zinc corrodes in solution having $\mathrm{pH}$ lower than 6.0 and higher than 12.5 , while within this range the corrosion is very slow ${ }^{2}$. Hydrochloric acid is highly corrosive, strong mineral acid since it is completely dissociated in water and has major industrial uses.

Aromatic, aliphatic and heterocyclic amines have been extensively investigated as corrosion inhibitors ${ }^{3-5}$. According to Hackerman et al. ${ }^{6-7}$ the inhibitive properties of a series of secondary aliphatic and cyclic amines in acid media are controlled by the percentage of $\pi$ - orbital of free electron on the nitrogen atom of these compounds. R.T.Vashi et al. ${ }^{8-9}$ studied the corrosion inhibitor of zinc in $\left(\mathrm{HNO}_{3}+\mathrm{HCl}\right)$ by ethanolamines and by ethylamines. R.T.Vashi et al. ${ }^{10}$ studied aniline as corrosion inhibitor for zinc in phosphoric acid.

In the present study, aniline has been evaluated as a corrosion inhibitor for zinc in hydrochloric acid using weight loss and potentiodynamic polarisation. 


\section{Experimental}

Zinc plates samples with the composition $99.96 \% \mathrm{Zn}, \mathrm{Pb}-0.02 \% \max$. Cd $-0.01 \%$ and Fe- $0.01 \%$ were used. For weight loss measurements metal specimen of the size $4.65 \times 2.15 \times$ $0.16 \mathrm{~cm}$ dimension having an area of $0.2221 \mathrm{dm}^{2}$ of commercial grade zinc with small hole of $7.9 \mathrm{~mm}$ diameter near the upper edge were used. The specimens were degreased with acetone and dried in warm air using air drier and preserve in dessicator till use.

\section{Weight loss measurements}

The test specimens were immersed in concentration of $0.01,0.05,0.10$ and $0.15 \mathrm{M} \mathrm{HCl}$ with and without inhibitors. One specimen only suspended by glass hook, in each beaker containing $230 \mathrm{~mL}$ of the solution and was open to air at room temperature (301 K) for $24 \mathrm{~h}$. The effect aniline as a inhibitor with 5, 10, 15 and $20 \mathrm{mM}$ concentration was studied to understand the corrosion behaviour. After the test, specimens were cleaned by $10 \%$ chromic acid solution having $0.2 \% \mathrm{BaCO}_{3}$ for a period of about 2 minutes ${ }^{11}$. After cleaning, test specimens were washed with distilled water followed by acetone and dried with air drier. The mean value of weight loss was reported as $\mathrm{mg} / \mathrm{dm}^{2}$ shown in Table 1 . All chemicals used were of AR grade. The test solution was prepared in double distilled water.

To study the effect of temperature on corrosion of zinc in $0.05 \mathrm{M} \mathrm{HCl}$, the specimens were immersed in $230 \mathrm{~mL}$ of corrosive solution and corrosion rate was determined at various temperatures such as 303, 313, 323 and $333 \mathrm{~K}$ for an immersion period of $2 \mathrm{~h}$ with and without inhibitor. From the data, I.E., energy of activation $\left(E_{a}\right)$, heat of adsorption $\left(\mathrm{Q}_{\mathrm{ads}}\right)$, free energy of adsorption $(\Delta \mathrm{Ga})$, change of enthalpy $(\Delta \mathrm{H})$ and entropy of adsorption $(\Delta \mathrm{S})$ were calculated and shown in Table 2.

\section{Potentiodynamic polarization measurements}

For polarization study, metal specimens having an area of $0.2221 \mathrm{dm}^{2}$ were immersed in $230 \mathrm{~mL}$ corrosive solution without and with $20 \mathrm{mM}$ inhibitor concentration in $0.01 \mathrm{M} \mathrm{HCl}$. The test cell includes the metal specimen as a working electrode, corrosive solution in which the specimen was placed and saturated calomel electrode (SCE) as a reference electrode as well as platinum electrode as an auxiliary electrode. The polarization study was made by using potentiostat / galvanostat make Gamry, USA with inbuilt corrosion software. Polarization curves were plotted with potential against log current density (called Tafel plots). Cathodic and anodic polarization curves give cathodic and anodic Tafel lines correspondingly. The intersect point of cathodic and anodic Tafel lines gives the corrosion current $\left(\mathrm{I}_{\text {corr }}\right)$ and the corrosion potential $\left(\mathrm{E}_{\text {corr }}\right)^{12}$.

\section{Results and Discussion}

The results are presented in Tables 1 to 3 and in Figure 1 to 4 . To assess the effect of corrosion of zinc in hydrochloric acid, aniline was added as inhibitor. I.E. has been calculated as follows:

$$
\text { I.E. } \%=\frac{W_{u}-W_{i}}{W_{u}} \times 100
$$

Where, $\mathrm{W}_{\mathrm{u}}$ is the weight loss of metal in uninhibited acid and $\mathrm{W}_{\mathrm{i}}$ is the weight loss of metal in inhibited acid. Energy of activation (Ea) has been calculated from the slope of $\log \rho$ versus $1 / \mathrm{T}$ as shown in Figure 1 ( $\rho=$ corrosion rate, $\mathrm{T}=$ absolute temperature $)$ and also with the help of the Arrhenius equation ${ }^{13}$.

$$
\log \frac{\rho_{2}}{\rho_{1}}=\frac{E a}{2.30 \boldsymbol{B}} \quad\left[\left(1 / T_{1}\right)-\left(1 / T_{2}\right)\right]
$$


Table 1. Corrosion rate (CR) and inhibition efficiency (I.E.) of zinc in $0.01,0.05,0.10$ and $0.15 \mathrm{M} \mathrm{HCl}$ containing aniline as inhibitor for an immersion period of $24 \mathrm{~h}$ at $301 \pm 1 \mathrm{~K}$

\begin{tabular}{|c|c|c|c|c|c|c|c|c|c|}
\hline \multicolumn{10}{|c|}{ Acid concentration } \\
\hline \multirow[b]{2}{*}{ 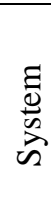 } & \multirow{2}{*}{  } & \multicolumn{2}{|c|}{$0.01 \mathrm{M}$} & \multicolumn{2}{|c|}{$0.05 \mathrm{M}$} & \multicolumn{2}{|c|}{$0.10 \mathrm{M}$} & \multicolumn{2}{|c|}{$0.15 \mathrm{M}$} \\
\hline & &  & $\begin{array}{c}\text { I.E. } \\
\%\end{array}$ & $\begin{array}{c}\mathrm{CR} \\
\mathrm{mg} / \mathrm{dm}^{2}\end{array}$ & $\begin{array}{c}\text { I.E. } \\
\%\end{array}$ & $\begin{array}{c}\mathrm{CR} \\
\mathrm{mg} / \mathrm{dm}^{2}\end{array}$ & $\begin{array}{l}\text { I.E. } \\
\%\end{array}$ & $\begin{array}{c}\mathrm{CR} \\
\mathrm{mg} / \mathrm{dm}^{2}\end{array}$ & $\begin{array}{l}\text { I.E. } \\
\%\end{array}$ \\
\hline $\mathrm{A}$ & -- & 81.98 & - & 1136.48 & - & 3151.05 & - & 5221.85 & - \\
\hline \multirow[t]{4}{*}{ B } & 5 & 6.30 & 92.32 & 316.97 & 72.11 & 1565.96 & 50.30 & 3353.89 & 35.77 \\
\hline & 10 & 3.60 & 95.61 & 212.06 & 81.34 & 1178.75 & 62.59 & 2946.87 & 43.57 \\
\hline & 15 & 2.25 & 97.26 & 108.51 & 90.45 & 715.44 & 77.30 & 2119.76 & 59.41 \\
\hline & 20 & 0.90 & 98.90 & 38.27 & 96.63 & 378.66 & 87.98 & 1512.38 & 71.04 \\
\hline
\end{tabular}

Table 2. Effect of temperature on corrosion rate (CR), inhibitive efficiency (I.E \%.), energy of activation ( $\left.E_{a}\right)$, heat of adsorption $\left(\mathrm{Q}_{\mathrm{ads}}\right)$ and free energy of adsorption $\left(\Delta \mathrm{G}^{\circ}{ }_{\mathrm{a}}\right)$ for zinc in $0.05 \mathrm{M} \mathrm{HCl}$ containing inhibitor

Inhibitor concentration $=20 \mathrm{mM}$, Immersion period $=2 \mathrm{~h}$. Effective area of specimen $=0.2221 \mathrm{dm}^{2}$

\begin{tabular}{|c|c|c|c|c|c|c|c|c|c|c|c|c|c|c|c|c|}
\hline \multirow{3}{*}{ 吾 } & \multicolumn{8}{|c|}{ Temperature, K } & \multirow{3}{*}{$\begin{array}{c}\begin{array}{c}\text { Mean } \\
\mathrm{E}_{\mathrm{a}}\end{array} \\
\text { From } \\
\begin{array}{c}\mathrm{Eq}(1) \\
\mathrm{kJ} \mathrm{mol}^{-1}\end{array}\end{array}$} & \multirow{2}{*}{$\begin{array}{c}\begin{array}{c}\mathrm{E}_{\mathrm{a}} \\
\text { From }\end{array} \\
\text { Arrhenius }\end{array}$} & \multicolumn{6}{|c|}{ Mean value } \\
\hline & 303 & & 313 & & 323 & & 333 & & & & & $\mathrm{bs}, \mathrm{kJ} \mathrm{m}$ & $\mathrm{ol}^{-1}$ & & $\mathrm{~J} \mathrm{~mol}^{-1}$ & \\
\hline & $\begin{array}{c}\mathrm{CR} \\
\mathrm{mg} / \mathrm{dm}^{2} \\
\end{array}$ & $\begin{array}{c}\text { I.E. } \\
2 \quad \% \\
\end{array}$ & $\begin{array}{c}\mathrm{CR} \\
\mathrm{mg} / \mathrm{dm}^{2}\end{array}$ & $\begin{array}{c}\text { I.E. } \\
\%\end{array}$ & $\begin{array}{c}\text { CR } \\
\mathrm{mg} / \mathrm{dm}^{2}\end{array}$ & $\begin{array}{c}\text { I.E. } \\
\%\end{array}$ & $\begin{array}{c}\mathrm{CR} \\
\mathrm{mg} / \mathrm{dm}^{2}\end{array}$ & $\begin{array}{c}\text { I.E. } \\
\%\end{array}$ & & $\begin{array}{c}\text { Plot } \\
\mathrm{kJ} \mathrm{mol}^{-1}\end{array}$ & $\begin{array}{c}303- \\
313\end{array}$ & $\begin{array}{c}313- \\
323\end{array}$ & $\begin{array}{l}323- \\
333\end{array}$ & $\Delta \mathrm{G}_{\mathrm{a}}$ & $\Delta \mathrm{H}_{\mathrm{a}}$ & $\Delta \mathrm{S}_{\mathrm{a}}$ \\
\hline A & 773.98 & - & 949.12 & - & 1594.78 & - & 2185.05 & - & 29.29 & 34.19 & - & - & - & - & - & - \\
\hline $\mathrm{B}$ & 8.55 & 99.89 & 21.61 & 97.72 & 60.78 & 96.19 & 155.79 & 92.87 & 81.41 & 80.29 & 57.70 & 44.49 & 59.19 & 30.16 & 78.81 & 0.35 \\
\hline
\end{tabular}


Where, $\rho_{1}$ and $\rho_{2}$ are the corrosion rate at temperature $T_{1}$ and $T_{2}$ respectively. The value of heat of adsorption $\left(\mathrm{Q}_{\mathrm{ads}}\right)$ were calculated by the following equation ${ }^{12,13}$.

$$
\mathrm{Q}_{\text {ads }}=2.303 \mathrm{R}\left[\log \left(\theta_{2} / 1-\theta_{2}\right)-\log \left(\theta_{1} / 1-\theta_{1}\right)\right] \times\left[\mathrm{T}_{1} \cdot \mathrm{T}_{2} / \mathrm{T}_{2}-\mathrm{T}_{1}\right]
$$

Where, $\theta_{1}$ and $\theta_{2}[\theta=(\mathrm{Wu}-\mathrm{Wi}) / \mathrm{Wi}]$ are the fractions of the metal surface covered by the inhibitors at temperature $T_{1}$ and $T_{2}$ respectively. The values of the free energy of adsorption $\left(\Delta G_{a}\right)$ were calculated with the help of the following equation ${ }^{14}$.

$$
\log C=\log (\theta / 1-\theta)-\log B
$$

Where, $\log \mathrm{B}=-1.74-\left(\Delta \mathrm{G}_{\mathrm{a}} / 2.303 \mathrm{RT}\right)$ and $\mathrm{C}$ is the inhibitor concentration. The enthalpy of adsorption $\left(\Delta \mathrm{H}_{\mathrm{a}}^{\circ}\right)$ and entropy of adsorption $\left(\Delta \mathrm{S}_{\mathrm{a}}^{\circ}\right)$ are calculated using the equation.

$$
\begin{aligned}
\Delta \mathrm{H}_{\mathrm{a}}^{\circ} & =\mathrm{E}_{\mathrm{a}}-\mathrm{RT} \\
\Delta \mathrm{S}^{\circ}{ }_{\mathrm{a}} & =\Delta \mathrm{H}-\Delta \mathrm{G} / \mathrm{T}
\end{aligned}
$$

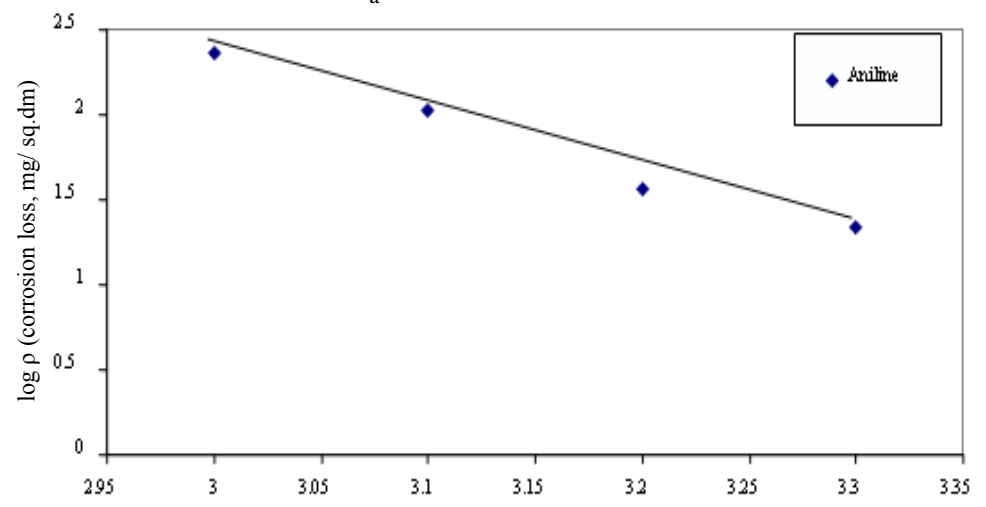

Figure 1. Arrhenius plots for corrosion of zinc in $0.05 \mathrm{M} \mathrm{HCl}$ in presence of $10 \mathrm{mM}$ inhibitor concentration

\section{Effect of temperature}

Table 2 shows that as the temperature increases corrosion rate increases while percentage of I.E. decreases. Mean ' $E_{a}$ ' values were calculated by using Eq. 2 for zinc in $0.05 \mathrm{M} \mathrm{HCl}$ is $29.29 \mathrm{kJmol}^{-1}$ while in acid containing inhibitor, the mean $\mathrm{E}_{\mathrm{a}}$ value (81.41) are found to be higher than that of uninhibited system.(Table 2). The higher values of mean $E_{a}$ indicate physical adsorption of the inhibitors on metal surface ${ }^{15}$. The values of $E_{a}$ calculated from the slope of Arrhenius plot and using Eq. 2 are almost similar. From Table 2, it is evident that in all cases, the $Q_{\text {ads }}$ values are negative and ranging from -59.19 to $-44.49 \mathrm{kJmol}^{-1}$. The mean $\Delta \mathrm{G}_{\mathrm{a}}$ value was negative $\left(-30.11 \mathrm{~kJ} \mathrm{~mol}^{-1)}\right.$. This suggests that they are strongly adsorbed on the metal surface. This statement was supported by the work of Talati and Darji ${ }^{16}$. The enthalpy changes $\left(\Delta \mathrm{H}_{\mathrm{a}}^{\circ}\right)$ is positive $\left(78.81 \mathrm{kJmol}^{-1}\right)$ indicating the endothermic nature of the reaction ${ }^{17}$ suggesting that higher temperature favours the corrosion process. The entropy $\left(\Delta \mathrm{S}_{\mathrm{a}}^{\circ}\right)$ values is positive $\left(0.35 \mathrm{kJmol}^{-1}\right)$ confirming that the corrosion process is entropically favourable ${ }^{18}$.

\section{Mechanism of corrosion inhibitor}

Generally, zinc dissolve in hydrochloric acid solution due to somewhat hydrogen type of attack, the reaction taking place at the microelectrodes of the corrosion cell being represented as, 


$$
\mathrm{Zn} \text {-------> } \mathrm{Zn}^{+2}+2 \mathrm{e}^{-} \text {(anodic reaction) }
$$

Reduction reaction is indicated by decrease in valence or the consumption of electrodes, as shown by the following equation.

$$
\begin{aligned}
2 \mathrm{H}^{+}+2 \mathrm{e}^{-}------->2 \mathrm{H} \text { (ads.) (cathodic reaction) } & \text { or } \mathrm{H}+\mathrm{H}_{3} \mathrm{O}^{+}+\mathrm{e}^{-}------->\mathrm{H}_{2} \uparrow+\mathrm{H}_{2} \mathrm{O}
\end{aligned}
$$

Hydrogen chloride $(\mathrm{HCl})$ is a monoprotic acid, which means it can dissociate (i.e., ionize) only once to give up one $\mathrm{H}^{+}$ion (a single proton). In aqueous hydrochloric acid, the $\mathrm{H}^{+}$joins a water molecule to form a hydronium ${ }^{19-20}$ ion, $\mathrm{H}_{3} \mathrm{O}^{+}$:

$$
\mathrm{HCl}+\mathrm{H}_{2} \mathrm{O} \rightarrow \mathrm{H}_{3} \mathrm{O}^{+}+\mathrm{Cl}^{-}
$$

The mechanism of inhibitor of corrosion is believed to be due to the formation and maintenance of a protective film on the metal surface. Further, when $\log (\theta / 1-\theta)$ is plotted against $\log \mathrm{C}$ straight line (Figure 2) is obtained in the case of inhibitor used. This suggests that the inhibitor cover both the anodic as well as cathodic regions through general adsorption following Langmuir isotherm.

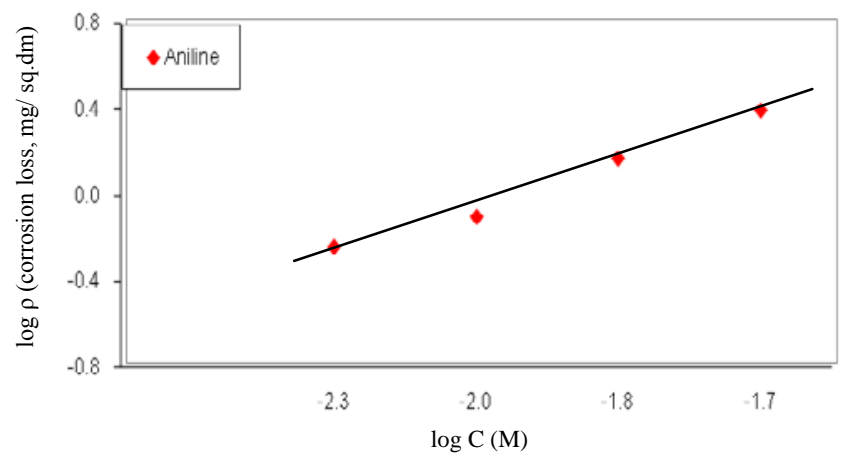

Figure 2. Plot of $\log (\theta / 1-\theta)$ versus $\log \mathrm{C}$ for inhibitor in $0.15 \mathrm{M} \mathrm{HCl}$

Due to resonance, in aniline the lone pair of electrons on the nitrogen atom is less available for coordination with a proton than that in aliphatic amines where the phenomenon of resonance is not possible. In addition to this, the small positive charge on the $N$-atom in aniline due to resonance tends to repel the proton. Thus, aniline becomes less basic ${ }^{21}$. Aniline on accepting a proton may give a small concentration of the cation $\mathrm{C}_{6} \mathrm{H}_{5}{ }^{+} \mathrm{NH}_{3}$ (onium) which does not show resonance. As there is more resonating structures possible for aniline than for onium ion, the former will be stabilized with respect to the latter ${ }^{22}$.

It appears that nitrogen atom of amino group $\left(-\mathrm{NH}_{2}\right)$ in aniline acts as the reaction centre (polar function) because of its higher electron density. This reaction centre forms a monolayer on the zinc surface. Moreover, aniline assumes a small positive charge in acid solutions due to protonation of amino $\left(-\mathrm{NH}_{2}\right)$ group, higher electron density of the nitrogen atom facilitates the protonation. As the concentration increases the rate of protonation also increases. The successive increase in protonation may be responsible, in many cases, for the enhancement of the I.E.

\section{Polarization behaviour}

Anodic and cathodic galvenostatic polarization data shown in Table 3. Polarization curve shown in Figure 3 and Figure 4 indicates polarisation of both anodes as wells cathodes. In almost all the cases, the I.E. from Tafel plots agree well (within $\pm 4 \%$ ) with the values obtained from weight loss data. 
Table 3. Polarisation data and inhibition efficiency (I.E.) of aniline for zinc in $0.01 \mathrm{M} \mathrm{HCl}$ at $301 \pm 1 \mathrm{~K}$

\begin{tabular}{|c|c|c|c|c|c|c|c|}
\hline \multirow{2}{*}{ 离 } & \multirow[b]{2}{*}{$\begin{array}{l}E_{\text {corr }} \\
m V\end{array}$} & \multirow{2}{*}{$\begin{array}{c}\mathrm{CD} \\
\mathrm{I}_{\text {corr }} \\
\mathrm{mA} / \mathrm{cm}^{2}\end{array}$} & \multicolumn{3}{|c|}{ Tafel slope, $\mathrm{mV} /$ decade } & \multicolumn{2}{|c|}{ I.E., \% from methods } \\
\hline & & & $\begin{array}{c}\text { Anodic } \\
\beta_{\mathrm{a}} \\
\end{array}$ & $\begin{array}{c}\text { Cathodic } \\
-\beta_{c}\end{array}$ & $\begin{array}{c}\mathrm{B}, \\
\mathrm{mV}\end{array}$ & $\begin{array}{c}\text { By } \\
\text { weight loss }\end{array}$ & $\begin{array}{c}\text { By } \\
\text { polarization }\end{array}$ \\
\hline $\mathrm{A}$ & -1040 & 0.1190 & 36.36 & 277.77 & 13.96 & - & - \\
\hline B & -1050 & 0.0063 & 55.55 & 111.11 & 16.10 & 98.90 & 94.71 \\
\hline
\end{tabular}

$\mathrm{A}=\mathrm{HCl} \quad \mathrm{B}=\mathrm{HCl}+$ aniline

$\beta_{\mathrm{a}}=$ Anodic Tafel constant, $\beta_{\mathrm{C}}=$ Cathodic Tafel constant. $\mathrm{CD}=$ Corrosion current density from interception of anodic and cathodic lines.



Figure 3. Potentiodynamic polarization curve of Zinc in $0.01 \mathrm{M} \mathrm{HCl}$ in absence of inhibitor

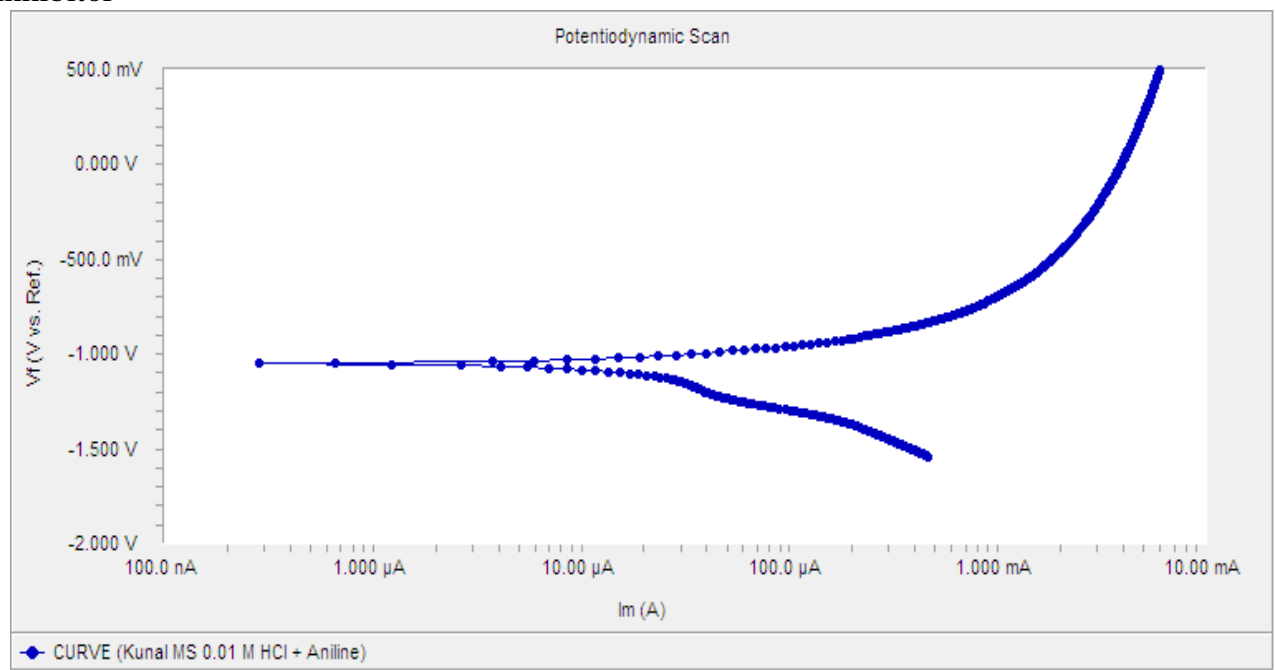

Figure 4. Potentiodynamic polarization curve of Zinc in $0.01 \mathrm{M} \mathrm{HCl}$ in presence of $20 \mathrm{mM}$ inhibitor 


\section{Conclusion}

1. As the acid concentration increases the corrosion rate increases.

2. At constant inhibitor concentration, the I.E. of inhibitor decreases as the concentration of acid increases.

3. At all concentration of acid, as the inhibitor concentration increases I.E. increases and corrosion rate decreases.

4. Addition of inhibitor in corrosive media indicates that as the temperature increases corrosion rate increases while I. E. decreases.

\section{References}

1. Koch G H, Brongers M P H, Thompson N G, Virmani Y P and Payer J H, Corrosion Cost and Preventive Strategies in the United States, CC Technologies Laboratories, Inc., Federal Highway Administration, FHWA-RD-01-XXX, Sept. 2001.

2. $\quad$ Shreir L L, Corrosion, George Newnes Ltd., London, 1963, 37.

3. Hackerman M and Sudbery J D, J Electrochem Soc., 1950, 97, 109.

4. $\quad$ Unni V K V and Ramachar J C, J Electrochem Soc., Japan, 1965, 33, 557.

5. Patel N K, Sampat S S, Vora J C and Trivedi R M, Werkst Korros., 1970, 10, 809.

6. Hackerman N and Hurd R M, Proc $1^{\text {st }}$ Int Congr Met Corros Butterworths, UK, 1961, 16.

7. Hackerman N, Annali Uni. Ferrara N S Sez, Suppl., 1961, 3, 99.

8. Vashi R T and Bhajiwala H M, Der Pharma Chemica, 2010, 2(4), 51-56.

9. Vashi R T and Bhajiwala H M, Bull Electrochem., 2002, 8(6), 261-266.

10. Vashi R T and Naik Diksha, Int J Chem Tech Res., 2011, 3(2), 864-869.

11. Stroud E G, J Appl Chem., 1951, 1, 93-95.

12. Uhlig H H, Corr and Corr Cont., Wiley, USA, 1967, 18.

13. Subramanian N and Ramakrishnaiah K, Indian J Technol., 1970, 8, 369.

14. Abdel A M S and Saied A E L, Trans SAEST, 1981, 16, 197.

15. Putilova I N, Barannik V P and Balezin S A, Metallic Corrosion Inhibitors, Pergamon Press, Oxford, 1960, 30-32.

16. Talati J D and Darji J M, J Indian Chem Soc., 1988, LXV, 94-99.

17. Agrawal D et al., Trans SAEST, 2003, 38, 111-114.

18. Issa R M, El-Sonbati A Z, El-Bindary A A and Kera H M, Eur Polym J., 2002, 38, 561.

19. Smithells C J, Metals Reference Book, Butterworth, London, 1967.

20. Taril B C, The Properties of Zinc, Consolidated Mining and Smelting Company of Canada, 1956.

21. Rashwan S M, Abdel-Wahab S, El-tanany A Z and Ali M, Bull Electrochem., 1997, 13(12), 448-455.

22. Chatwal G R, Reaction Mechanism and Reagent in Organic Chemistry, 1997, 74. 